\title{
ROOLIHAHMOT PUHEESSA JA NÄYTTÄMÖLLÄ - OSALLISTUMISEN KEHYKSET JA AMMATILLINEN KATSE TEATTERIHARJOITUSTEN VUOROVAIKUTUKSESSA
}

\author{
Liisa Raevaara, Helsingin yliopisto, \\ Kotimaisten kielten keskus
}

\begin{abstract}
Artikkelissa tarkastellaan nuorille aikuisille suunnatun teatteriprojektin harjoituksia ja niihin sisältyviä tilanteita, joissa puhutaan roolihahmoista ja roolihahmona toimimisesta. Tutkimus on keskustelunanalyyttinen ja kytkeytyy erityisesti vuorovaikutuksen multimodaalisuutta, kehollisten ja kielellisten resurssien käyttöä ja koordinointia tarkastelevaan tutkimukseen. Se täydentää myös tutkimuksia läsnäolijoihin viittaamisen käytänteistä vuorovaikutuksessa. Artikkelissa osoitetaan, miten läsnäolijoihin viittaavien kielellisten elementtien valinta sekä osanottajien kehollinen toiminta ja tilan käyttö rakentavat toiminnan osallistumiskehikkoa ja roolihahmon tarkastelun näkökulmia. Samalla ne rakentavat teatteriprojektin osanottajien kahdentunutta roolia esiintyjinä ja roolihahmoina sekä teatterityön ammatillista katsetta.
\end{abstract}

Avainsanat: ammatilliset käytänteet, keskustelunanalyysi, läsnäolijoihin viittaaminen, multimodaalisuus, osallistumiskehikko, teatterivuorovaikutus

\section{JOHDANTO}

Kirjassaan Frame Analysis (1974) Erving Goffman tarkastelee sosiaalista toimintaa jäsentäviä kehyksiä erilaisissa konteksteissa, muun muassa teatterissa (mt: 124-144). Hän kuvaa, miten teatteriesityksessä toiminnan ja sen tulkinnan kehystä rakentavat ennen kaikkea osallistujien liikkuminen ja positiot fyysisessä tilassa. Kun yksilö astuu näyttämölle, hän muuntuu katsomossa istuvan yleisön silmissä fiktiiviseksi roolihahmoksi. Draamakasvatuksessa samaa prosessia on tarkasteltu roolihahmoksi muuntautuvan yksilön näkökulmasta. Esteettisen kahdentumisen käsitteellä kuvataan sitä, miten draamassa toiminen edellyttää toimijalta tietoisuutta kahdentuneesta roolistaan: siirtyessään fiktiiviseen rooliin hänen tulee samalla tiedostaa, että todellisuuskin on edelleen läsnä ja samanaikaisesti olemassa (esim. Heikkinen, 2004, s. 102-105; myös Ihalainen, 2017, tulossa).

Kirjoittajan yhteystiedot:

Liisa Raevaara

liisa.raevaara@kotus.fi 
Artikkelissani tarkastelen nuorille aikuisille suunnatun teatteriprojektin harjoituksia. Projektiin osallistuvilla nuorilla ei ole aiempaa kokemusta teatterin tekemisestä, ja projektin aikana he harjoittelevat roolihahmoksi muuntautumisen tapoja ja tekniikoita teatterityön ammattilaisen ohjauksessa. Samalla he oppivat tarkastelemaan ja arvioimaan luomiaan roolihahmoja myös ulkopuolisesta näkökulmasta, yleisön silmin ja osana tulevaa esitystään. Tutkin harjoituksiin sisältyviä tilanteita, joissa puhutaan roolihahmona toimimisesta tai tämän toiminnan rakentamista roolihahmoista. Selvitän, miten osanottajat näissä tilanteissa muokkaavat kielellisellä ja kehollisella toiminnallaan roolihahmon tarkastelun näkökulmia ja miten näiden näkökulmien vuorottelu ja limittyminen rakentavat osallistujien kahdentunutta roolia esiintyjinä ja roolihahmoina sekä samalla teatterityön ammatillista katsetta (C. Goodwin, 1994, 2000a, 2018).

\section{TUTKIMUSKOHTEENA TEATTERIVUOROVAIKUTUS}

Tutkimukseni on keskustelunanalyyttinen, ja se valottaa yhdenlaisen ammatillisen tilanteen vuorovaikutuskäytänteitä. Vaikka erilaisia ammatillisia vuorovaikutustilanteita on keskustelunanalyysin piirissä tutkittu hyvinkin laajasti ja kauan, teatterin vuorovaikutus on uusi ja vähän tutkittu alue (ks. kuitenkin esim. Harjunpää, Deppermann \& Sorjonen, 2021; Hazel, 2015, 2018; Norrthon, 2020; Savijärvi \& Ihalainen, tulossa; Schmidt, 2014, 2018).

\subsection{Kebollinen ja kielellinen toiminta, tila ja objektit vuorovaikutuksessa}

Teatterityössä keskeisiä työn ja vuorovaikutuksen resursseja ovat kehollisuus sekä fyysiseen tilaan, erityisesti näyttämöön ja katsomoon kytkeytyvät merkitykset, yhdessä kielellisen toiminnan kanssa. Teatterivuoro- vaikutuksen tutkimus syventääkin osaltaan ymmärrystä vuorovaikutuksen multimodaalisuudesta. Varsinkin viimeisen kymmenen vuoden aikana multimodaalisuuden tarkastelu on noussut keskustelunanalyyttisen tutkimuksen keskiöön (Nevile, 2015) - vaikkakin se on ollut mukana tutkimuksessa jo keskustelunanalyysin alkuajoista lähtien (esim. C. Goodwin, 1979; M. H. Goodwin, 1980; Heath, 1986; ks. myös C. Goodwin, 2018).

Tutkimuksissa on osoitettu, miten osanottajat käyttävät vuorovaikutuksen rakentamisessa ja tulkinnassa resurssina kielellisen ja kehollisen toiminnan koordinointia, materiaalista kontekstia ja objekteja sekä liikkumista ja positioita tilassa (esim. Deppermann \& Streeck, 2018; C. Goodwin, 2000b, 2018; Haddington, Mondada \& Nevile, 2013; Keevallik, 2010; Mondada, 2014, 2018). Erilaisissa institutionaalisissa tilanteissa keskeinen resurssi toiminnan jäsentämisessä ja tulkinnassa on se, miten osanottajat liikkuvat ja kehollisesti orientoituvat suhteessa institutionaalisten tehtäviensä kannalta keskeisiin fyysisen tilan alueisiin ja objekteihin (esim. C. Goodwin, 1994, 2000a; Harjunpää, Mondada \& Svinhufvud, 2018; Mortensen \& Hazel, 2014; Sorjonen \& Raevaara, 2014).

\subsection{Teatteriharjoitusten osallistumiskehikko}

Teatteriprojektin osanottajat toimivat harjoitusten aikana sekä esiintyjinä että roolihahmoina. Suuntautuminen näiden roolien vaihteluun, sekä yhtäaikaisuuteen että erillisyyteen, tulee vuorovaikutuksessa näkyviin muun muassa siinä, miten osanottajat rakentavat ja muokkaavat meneillään olevan toiminnan osallistumiskehikkoa (participation framework). Osallistumiskehikon käsitteen esitteli Erving Goffman (1981, s. 124-159) kuvatessaan puhetilanteen osanottajien puhujan ja kuulijan - jakautumista useammanlaisiksi puhujiksi ja kuulijoiksi. Keskus- 
telunanalyyttisessa tutkimuksessa osallistumiskehikon käsitettä ja sen käyttöä analyysin välineenä ovat kehittäneet ennen kaikkea Charles ja Marjorie Harness Goodwin.

Osallistumiskehikko koostuu alati vaihtuvista osallistujapositioista. Kehikkoa muokatessaan vuorovaikutuksen osanottajat suuntautuvat monenlaisiin toiminnan dimensioihin ja hyödyntävät monenlaisia resursseja, vuorojen muotoilua, katseiden suuntaa, eleitä, kehollisia orientaatioita ja osallistujien liikkumista ja positioita tilassa. Toimintansa yksityiskohdilla he osoittavat samanaikaisesti sekä omaa että vastaanottajien asemaa suhteessa käsiteltävään asiaan, meneillään olevaan toimintaan ja toisiinsa. Yhdenkin lausuman aikana voi vaihtua esimerkiksi se, kuka on puhuteltu, ja sen myötä osallistujapositio, johon vuoro asettaa vastaanottajan. (Esim. C. Goodwin, 1979, 2007; C. Goodwin \& M. H. Goodwin, 1992, 2004.)

\subsection{Osanottajien kahdentunut rooli ja teatterityön ammatillinen katse}

Artikkelini valottaa sitä, millaiset teatterityölle ominaiset tulkintakehykset ja osanottajien positiot rakentuvat ja tulevat näkyviin teatteriharjoitusten kielellisessä ja kehollisessa toiminnassa. Tutkimus vahvistaa osaltaan keskustelunanalyyttista teatterivuorovaikutuksen tutkimusta. Se täydentää multimodaalisuuden tarkastelua erityisesti siitä näkökulmasta, miten kehollisen ja kielellisen toiminnan koordinointia sekä työssä olennaisia fyysisen tilan alueita käytetään vuorovaikutuksessa. Analyysissa keskeistä on se, miten teatteriharjoitusten osanottajat jäsentävät ja tulkitsevat toimintaansa ja asemiaan siinä käyttämällä resurssina merkityksiä, joita näyttämölle asettumiseen ja asettamiseen kytkeytyy.

Hyödynnän myös joitakin draamakasvatuksen käsitteitä ja näkökulmia, erityisesti näkemystä draamassa toimivien kahdentuneesta roolista. Draamakasvatuksessa toimijan kahdentunutta roolia tarkastellaan ennen kaikkea kognitiivisena ilmiönä ja prosessina: sen tiedostamisena, että fiktiiviseen rooliin siirryttäessä todellisuuskin on edelleen olemassa ja että fiktio ja todellisuus ovat yhtäältä erillisiä mutta myös samanaikaisesti läsnä (esim. Heikkinen, 2004, s. 85-90; myös Eriksson, 2009, s. 35-46). Tutkimuksessani tarkastelen sen sijaan sitä, miten osanottajien kahdentunut rooli rakentuu vuorovaikutuksen konkreettisissa yksityiskohdissa (Ihalainen, 2017, tulossa) ${ }^{1}$. Osoitan, miten harjoituksissa rakennetaan ja muokataan näkökulmia, joista roolihahmoja ja roolihahmona toimimista tarkastellaan, ja miten näiden näkökulmien vaihtelu ja limittyminen rakentaa toiminnan osallistumiskehikkoa ja sen myötä osanottajien kahdentunutta roolia.

Tutkimissani harjoitustilanteissa osanottajat opettelevat teatterityön tekniikoita ja osin tiedostamattomiakin teatterityön käytänteitä, periaatteita ja tulkintakehyksiä (vrt. Peräkylä \& Vehviläinen, 2003; Visakko, 2020a, 2020b). Niihin kuuluvat myös teatterityölle ominaiset ja työssä tarvittavat tavat hahmottaa ja tulkita osanottajien kehollista ja kielellistä toimintaa sekä fyysisen tilan merkityksiä. Pyrinkin osoittamaan, miten ne kielelliset ja keholliset vuorovaikutuskäytänteet, jotka rakentavat osanottajien kahdentunutta roolia esiintyjinä ja roolihahmoina, ohjaavat osaltaan myös sitä, millaisista näkökulmista ja millaisissa tulkintakehyksissä osanottajia ja heidän toimintaansa tilassa katsotaan, tulkitaan ja arvioidaan. Tarkastelen näiden vuorovaikutuskäytänteiden omaksumista osana teatterityön ammatillisen katseen omaksumista (professional vision, C. Goodwin, 1994, 2000a, 2018).

1 Kiitän Laura Ihalaista (Ihalainen 2017, tulossa, suulliset keskustelut) draamakasvatuksen käsitteiden esittelystä sekä huomiosta, että käsitteillä kuvatut, kognitiivisiksi nähdyt ilmiöt heijastuvat monin tavoin teatteriharjoitusten vuorovaikutuksessa. 


\section{TUTKIMUKSEN AINEISTO JA METODI}

Tutkimukseni on osa Koneen Säätiön rahoittamaa kielentutkijoiden ja taiteentekijöiden yhteishanketta Taide työnä ja työvälineenä (www.urbduuni.fi). Se on toiminut Suomen Akatemian rahoittamassa huippuyksikössä Intersubjektiivisuus vuorovaikutuksessa (HY) (http://blogs.helsinki.fi/intersubjectivity). Hanke tutkii, miten teatterityön ominaiset piirteet ilmenevät teatteriharjoitusten vuorovaikutuksessa, millaisen kehyksen teatteriprojekti tarjoaa erilaisten asioiden oppimiselle ja identiteettityölle ja mitä tapahtuu, kun tutkijat ja taiteentekijät työskentelevät yhdessä (esim. Ihalainen, 2017, tulossa; Izarra \& Sirviö, 2018; Malaska, 2017; Savijärvi \& Ihalainen, tulossa; Turunen, 2018; Visakko, 2017, 2020a, 2020b).

Hankkeemme seurasi nuorille aikuisille suunnatun teatteriprojektin, URB-Kesäduunin toimintaa 2014, 2015 ja 2016. Projekti toteutettiin osana Kiasma-teatterin Urbaanin taiteen festivaalia (URB), ja siihen palkattiin vuosittain 6-8 osallistujaa noin kuudeksi viikoksi. Heidän työnään oli valmistaa festivaalille esitys kahden taiteen ammattilaisen ohjauksessa. Osallistujilla ei ollut aiempaa kokemusta teatterin tekemisestä, ja projektissa he saivat kokeilla, mitä teatterin tekeminen on työnä. Esitykset eivät perustuneet valmiisiin käsikirjoituksiin, vaan sekä käsikirjoitus että esitys valmistettiin projektin aikana ryhmässä². Kesäduuneja 2014-2016 ohjanneet taiteen ammattilaiset työskentelivät myös Taide työnä ja työvälineenä -hankkeessa.

Hankkeen pääaineisto koostuu teatteriprojektin työskentelyn videonauhoituksista (noin 150 tuntia). Ne tehtiin kolmella kame-

2 Käytän termiä roolihahmo, koska aineistossa puheena olevat fiktiiviset hahmot eivät ole valmiin käsikirjoituksen tai näytelmän ennalta kuvattuja roolihenkilöitä vaan muuntuvia, usein vain hetken olemassa olevia hahmoja, joita projektin osanottajat toiminnallaan luovat. ralla, jotka oli sijoitettu eri puolille harjoitustilaa. Osallistuin itse osaan nauhoituspäivistä, ja niiden aikana tutkijat osallistuivat osin myös projektin harjoituksiin. Artikkelini aineistona ovat kesän 2014 nauhoitukset (noin 30 tuntia). Niistä poimin kaikki tilanteet, joissa puhutaan roolihahmoista tai roolihahmona toimimisesta (14 katkelmaa). Täydensin kokoelmaa yhdellä kesän 2015 harjoitustilanteella (42 min.), jossa osanottajat esittävät toisilleen lyhyitä kohtauksia ja esitysten välillä puhuvat niistä.

Tutkimissani tilanteissa ohjaaja kommentoi harjoitusta tai kohtausta, jonka projektin osanottajat ovat juuri tehneet tai jota he ovat aloittamassa, tai osanottajat itse esittävät tehtyyn tai kohta alkavaan harjoitukseen tai kohtaukseen liittyviä kommentteja, ehdotuksia tai tarkistuksia. ${ }^{3}$

Tutkimukseni metodina on keskustelunanalyysi, joka tarkastelee sosiaalisten normien ja käytänteiden ilmenemistä ja rakentumista vuorovaikutuksessa. Analysoimalla, miten osanottajat muotoilevat vuorojaan sekä kielellisesti että kehollisesti osaksi ajallisesti etenevää yhteistä toimintaa, voidaan selvittää, millaisiin tätä toimintaa jäsentäviin yhteisiin normeihin, käytänteisiin ja tulkintakehyksiin he yhteistyöllään suuntautuvat (esim. C. Goodwin, 2018; Heritage, 1996; Sacks, 1992; Sacks, Schegloff \& Jefferson, 1974; Schegloff, 2007; myös Stevanovic \& Lindholm, 2016).

Kun analysoidaan ja verrataan vuorojen muotoilua, toimintojen rakentamista ja vuorovaikutuksen resursseja erityyppisissä

3 En siis tarkastele tilanteita, joissa ohjaaja ohjaa osanottajien toimintaa roolihahmoina parhaillaan meneillään olevassa harjoituksessa. Niissä ei ole samanlaista näkökulmien vaihtelua kuin tutkituissa katkelmissa, vaan ohjaa käyttää pääasiassa 2. persoonan muotoja (ohjaajan direktiiveistä ks. Malaska, 2016). Tutkimieni katkelmien pituus vuoden 2014 aineistossa vaihtelee noin 1,5 minuutista noin 6 minuuttiin. Ne eivät kuitenkaan ole tarkkarajaisia. Kesän 2015 harjoitustilanteessa lähes kaikki puhe käsittelee roolihahmoja, joten siitä ei voi laskea katkelmien määrää. 
sekä arkisissa että ammatillisissa tilanteissa, voidaan tutkia yleisiä, eri tilanteissa toistuvia vuorovaikutuskäytänteitä ja myös eri tilanteiden eroja ja ominaispiirteitä. Näin karttuu tietoa muun muassa siitä, millaisin vuorovaikutuskäytäntein erilaisissa ammatillisissa konteksteissa hoidetaan työhön kuuluvia tehtäviä ja millaiset vuorovaikutuksen yksityiskohdat osoittavat osanottajien suuntautumista tilanteelle ominaisiin tulkintakehyksiin, toiminnan tavoitteisiin ja osanottajien rooleihin ja tehtäviin (esim. Antaki, 2011; Drew \& Heritage, 1992).

\section{NÄYTTÄMÖLLE}

\section{ASETTUMINEN RAKENTAA OSALLISTUJAPOSITIOITA}

Teatterissa keskeisiä ja merkityksellisiä fyysisen tilan alueita ovat näyttämö ja katsomo. Tarkastellessaan toiminnan ja sen tulkinnan kehysten rakentumista teatteriesityksen aikana Goffman (1974, s. 124-144) kuvaa, miten näyttämölle astuminen muokkaa yksilön ja tämän toiminnan tulkintakehystä: yksilö muuntuu roolihahmoksi katsomossa istuvan yleisön silmissä, ja yleisö näkee hänen toimintansa osana esitystä. Tilanteen osallistujien fyysiset positiot näyttämöllä ja katsomossa rakentavat heidän roolejaan tilanteessa ja sen myötä muokkaavat odotuksia ja tulkintoja, jotka säätelevät heidän toimintaansa ja vuorovaikutustaan (ks. myös C. Goodwin, 2000b).

Teatteriprojekteissa työskenneltiin esityksiin tarkoitetussa tilassa, jossa oli katsomo ja näyttämö. Kuten teatteriesityksissä myös harjoitustilanteissa osanottajat jäsentävät roolejaan ja toimintaansa orientoitumalla merkityksiin, joita näyttämöön ja katsomoon kytkeytyy. Harjoituksissa näyttämötilaan ja sen myötä roolihahmoksi asettuminen ei kuitenkaan liity vain esitystilanteisiin, jonkin kohtauksen läpikäyntiin tai harjoituksen aloittamiseen, vaan myös esimerkiksi tilanteisiin, joissa osanottajat esittävät harjoitukseen tai valmisteltavana olevaan kohtaukseen liittyviä kommentteja, tarkistuksia tai ehdotuksia.

Esimerkissä 1 Tuula, yksi projektin osanottajista esittää valmisteltavaan kohtaukseen liittyvän kommentin ja siirtyy samalla katsomosta näyttämölle. Näin hän muokkaa osallistumiskehikkoa ja tuo tilanteeseen mukaan roolihahmon, jonka hän asettaa muiden katseiden kohteeksi ja arvioitavaksi. Katkelman alussa nuoret istuvat katsomon etuosassa ja ohjaaja Elina ${ }^{4}$ seisoo näyttämöllä. Hän pohtii, miten kohtaus voisi edetä (r. 1-2), kun Tuula pyytää puheenvuoroa (ks. r. 2-3).
4 Elina Izarra oli Kesäduunien pääohjaaja niiden alusta lähtien. Artikkelin esimerkeissä hän esiintyy omalla nimellään. Kaikki muut esimerkkieni litteraatioissa esitetyt nimet ovat peitenimiä. 


\section{Esimerkki (1) [U087_Liikkuminen] ${ }^{5}$}

01 Elina: mut et se ele on enemmä niinku osoittaa;

04 Tuula: $\quad=$ mä miettiv vaa et sa aks me $<$ (.) saadaaks

05

06

07

08

09

10

11 Elina:

12 Tuula:

14 Elina:

16 Tuula: 17

(.) mut sit mä a âttelin sitä, (.) > kysy vạan Tüula, $=$

+ me (niinku - - - ), ++niinku, (0.5)

+tulee näyttämölle $++k a ̈ a ̈ n t y y$ katsomoon

[\#1] +sillee niinku, (1.5) liikkuu

+esittää käsillään eleitä

+ sii[s sillee et< $<++$ pitääks meijän

+ +käntyy oikeaan ++ tiputtaa kädet alas

[saatte;

[\#2] +niinku [oottaa ihan tälleen;]

+ seisoo asennossa rybdissä

[ $\uparrow \underline{e:: i ~ k u ~ t e i l l a ̈ h a ̈ ~ o n] ~}$

ne purkat siinä; (0.5) ja teil on ne papperit,

$[+>$ ai niii $<;]$

$[+$ rentouttaa rybdin

18 Elina: [mä anna]n ihaj just teille pür[kkaa;

19 Tuula:

[tôtta;

20 Elina: [ [\#3] +joo joo joo; (0.3) eni, êi tarvii olla

21 Tuula:

$$
\text { +kääntääkatseen Elinaan }
$$

22 Elina: näin; (0.3) siis toi loppukohta on sellanen

24

(0.3) et ku, todennäkösesti tos

25 Tuula: +loppukohdassa te ette liii $k \underline{u}$,

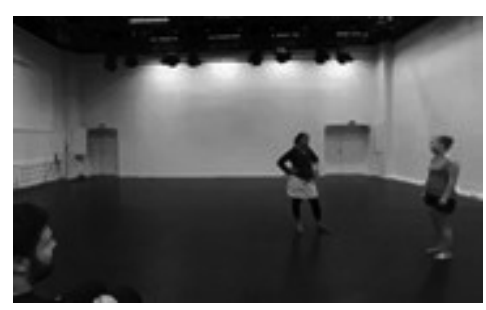

[\#3]

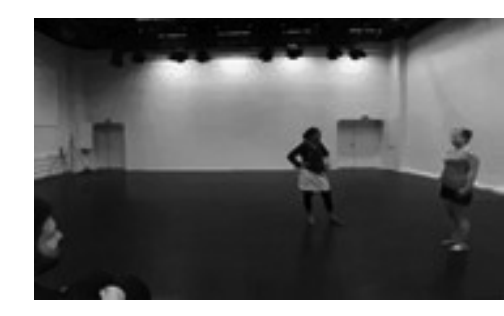

[\#2]

[\#1]

Elina Tuula

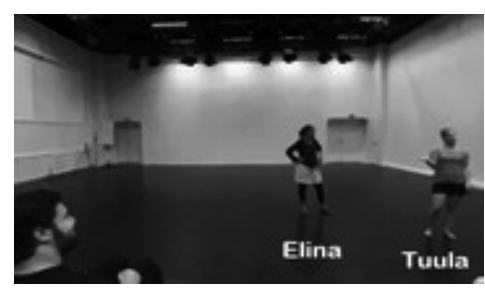


liseksi. Siten puheella rakennetun ja kuvatun toiminnan osallistujina ovat esiintyjät sekä kysymyksellä auktoriteettiasemaan asetettu ohjaaja. Tuulan samanaikainen kehollinen toiminta kuitenkin muokkaa tätä kielellisen toiminnan rakentamaa osallistumiskehikkoa.

Kun Tuula siirtyy katsomosta näyttämölle, hän muuntuu kehollisesti muiden katseiden kohteena olevaksi esityksen roolihahmoksi. Näyttämölle saavuttuaan Tuula myös kääntyy kohti katsomoa (kuva 1, r. 6-7), mikä korostaa roolihahmoksi asettumista. Samalla hän suuntautuu kehollisesti poispäin Elinasta ja kohti katsomossa istuvia muita esiintyjiä. Näin hän kutsuu myös heitä arvioimaan roolihahmon toimintaa ja hyväksymään ilmaisemansa näkemyksen siitä. Tuula siis hyödyntää fyysisen tilan merkityksiä siirtymällä näyttämölle ja asettumalla siten roolihahmoksi. Samalla hän rakentaa meneillään olevan toiminnan osallistumiskehikkoa tavalla, jonka voi nähdä ilmentävän teatterin tekemisen yhteisöllisiä käytänteitä - suuntautumista siihen, että esitystä luodaan yhdessä, ei vain ohjaajan vetämänä (ks. myös Visakko, 2020a, 2020b).

Tuulan kehollinen toiminta ilmaisee myös hänen asennoitumistaan vaihtoehtoihin, joita hän vuorossaan nostaa esiin, yhdessä puheen kanssa. Esittäessään vaihtoehdon, jota hän puheensa muotoilulla osoittaa itse suosivansa (r. 4-5: saadaaks me...), hän kääntyy kohti katsomossa istuvia muita esiintyjiä ja hakee näin heiltä arviota ja hyväksyntää ehdotukselleen (kuva 1, r. 7). Sen sijaan nostaessaan esiin vaihtoehdon, jonka hän puheensa muotoilulla merkitsee ei-toivotuksi (r. 9: pitääks meijän...), hän kääntyy kohti näyttämötilan sivuseinää mutta ei kuitenkaan Elinaan asti sekä asettuu seisomaan asennossa kädet sivuilla (kuva 2, r. 12). Suuntautumalla kehollisesti pois muista läsnäolijoista Tuula välttää hakemasta heidän hyväksyntäänsä tälle vaihtoehdolle. Negatiivista asennoitumista siihen Tuula ilmaisee myös korostetun liikkumattomalla jäykällä asennollaan (vrt. Keevallik, 20106).

Kääntyminen poispäin kaikista läsnäolijoista ylläpitää mielikuvaa esityksestä ja Tuulasta roolihahmona, samoin kädet sivuilla asennossa seisominen. Hetkeä myöhemmin, kun Elina on todennut, millaiseksi kohtaus on suunniteltu (r. 14-15), Tuula siirtyy kehollisesti pois roolihahmon positiosta. Samalla kun hän ilmaisee partikkelivuoroillaan muistavansa Elinan mainitsemat asiat (r. 16: ai niii, r. 19: tótta ; ks. Koivisto, 2013 ai nii(n) -vuorosta), hänen ryhtinsä ja asentonsa rentoutuu (r. 17). Sitten hän kääntää katseensa Elinaan (kuva 3, r. 20) ja lopuksi kävelee takaisin katsomoon (r. 25). Harjoitustilanteissa näyttämö ei ole ennalta rajattu tila kuten esityksissä yleensä, vaan näyttämönä toimii usein jokin pienempi alue laajasta näyttämötilasta. Sen rajat ja sijainti rakentuvat ja muokkautuvat kulloinkin meneillään olevan toiminnan mukaan, esimerkiksi sen myötä, mihin toimijat asettuvat tai mihin he esimerkiksi katsovat tai osoittavat kädellään.

Lisäksi näyttämötilaan kytkeytyviä merkityksiä on mahdollista hyödyntää muillakin tavoin kuin asettumalla itse näyttämölle. Kun projektin osanottajat puhuvat roolihahmoista ja niiden toiminnasta, he voivat asettaa puheena olevan referentin näyttämölle myös omalla kehollisella orientaatiollaan, katseensa ja eleidensä suunnalla. Näin tapahtuu esimerkissä 2. Se on harjoituksesta, jossa nuoret esittivät vuorotellen lyhyitä, itse keksimiään kohtauksia ja jonka tarkoituksena oli kokeilla, miten liikkumisen hidas tai nopea tempo vaikuttaa kohtauksen tulkintaan. Kunkin esityksen jälkeen keskusteltiin yhdessä sen herättämistä mielikuvista. Henry on juuri esittänyt kohtauksen, jossa hän käveli tuolin luo, joi tuolilla olevasta vesipullosta ja palasi lähtöpisteeseen.

6 Keevallik (2010) tarkastelee sitä, miten tanssinopettaja ohjaa oppilaita rakentamalla vuorojaan kielellisesti ja kehollisesti. Opettaja muun muassa esittää liioiteltuja tai karikoituja kehollisia lainauksia oppilaiden korjausta vaativista liikkeistä ja näin korostaa niiden eroa tavoiteltavana olevaan liikkeeseen. 


\section{Esimerkki(2)[U188_Tempo]}

01 Elina: $\quad$ mitäs sanotte. $(1.0)+$ mitä $\underline{\text { Amina sanoo. }}$ +katsoo Aminaa

03

04 Amina: $\quad$ +et se joi vêt(h)tä(h);

05 +katsoo Elinaa, muut katsovat Aminaa

06 Elina: $\quad$ se joi vettä?

$07 \quad$ (1.8) Elina katsoo Aminaa

08 Elina: +kạikki o sitä *mielt et se joi vaav vettä. +kääntää katseen Henryyn *Carlos, Elisa ja Nimo katsovat Henryyn

(1.0) Henry nyökyttelee

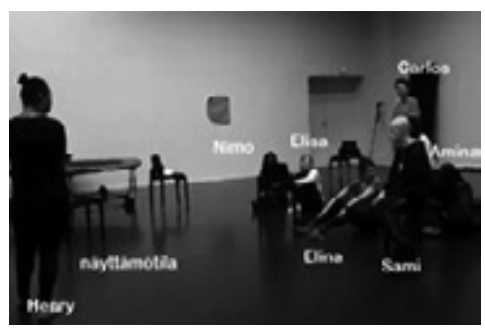

$[\# 1]$

12 Elina: $\quad[\# 1]+$ kaikkien mielest se joi vaan vettä, +katsoo Aminaa

14 (1.0) Carlos katsoo Henryä

15 (Elisa): [em_mä tiädä,]

16 Carlos: $\quad[$ no $>$ siis $<$ mun $]+$ mielest $[\# 2]$ se 17 +kääntää katseen kobti näyttämöä jotenki se niinku luulee juovansa ve[\#3] +vettä mut sit se juo jotain liimaa +viittaa kädellä kobti näyttämöä et se niinku, (0.4) muuttuu +tahmaseks jotenki. +kääntä̈ katseen Elinaan 24 Elina: okei? (1.0) joo?

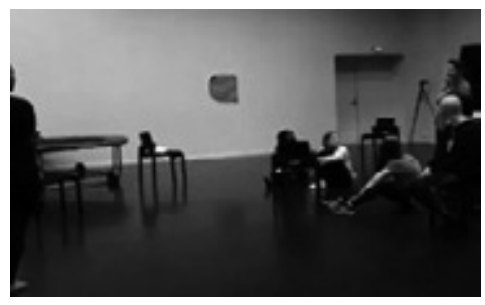

[\#2]

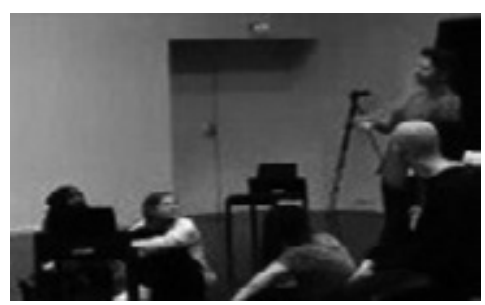

[\#3]
Elina pyytää nuoria kertomaan tulkinnoistaan ja suuntaa sitten kysymyksen Aminalle (r. 1). Vastatessaan Amina katsoo Elinaa, kuvaa Henryn esitystä menneessä aikamuodossa ja viittaa kohtauksen toimijaan se-pronominilla (r. 4). Vuoron aikana muut katsovat puolestaan Aminaa. Tilanteen voi rinnastaa sellaisiin arkitilanteisiin, joissa joku esittää toiseen läsnäolijaan liittyvän kertomuksen tai kuvauksen ja viittaa tähän kolmannen persoonan pronominilla se. Tällaisia arkitilanteita tutkineen Eeva-Leena Seppäsen (1998) mu- kaan läsnäolijaan viittaavalla se-pronominilla puhuja voi käsitellä referenttiä ensisijaisesti puheella luodun diskurssimaailman, esimerkiksi juuri kertomuksen hahmona sen sijaan, että aktivoisi tämän aseman puhetilanteessa esimerkiksi seuraavana puhujana ( $\mathrm{mt}$ : 45-58, 133-141, 152). Seppäsen mukaan tätä tulkintaa vahvistaa se, että keskustelijat eivät myöskään yleensä katso sitä läsnäolijaa, johon se-pronominilla viitataan, vaan pitävät katseensa puhujassa, joka puolestaan katsoo vastaanottajia (mt: 191-199, 205). 
Kun Amina esittää tulkintansa Henryn esityksestä, osanottajat suuntaavat katseitaan Seppäsen tarkastelemille arkitilanteille tyypilliseen tapaan. Amina katsoo Elinaa ja muut Aminaa. Aminan vuoron se-pronominin (r. 4) voikin tulkita kohtauksen esiintyjään Henryyn viittaavaksi. Carlos, joka seuraavaksi kertoo oman näkemyksensä esityksestä, kuitenkin muuttaa tätä katsekuviota ja samalla se-viittauksen tulkintaa.

Ennen Carloksen vuoroa alkua Elina summaa muiden tulkintoja ja katsoo Henryä (r. 8-9), mutta sen jälkeen taas Aminaa (kuva 1; r. 12-13). Elinan katsoessa Henryyn Carlos seuraa Elinan katsetta (r. 10) ja pitää katseensa Henryssä vuoronsa alkuun asti (kuva 1). Ryhtyessään kuvaamaan omaa tulkintaansa Henryn esityksestä (r. 16) hän kuitenkin muuttaa kehollista orientaatiotaan ja suuntaa katseensa äskeisen esityksen näyttämölle (kuva 2). Hetkeä myöhemmin hän viittaa myös kädellään kohti näyttämöä (kuva 3, r. 19-20). Tällä kehollisella suuntautumisellaan Carlos asettaa kuvaamansa tapahtuman ja sen toimijan, vuoronsa se-viittausten (r. 16, 18, $19,21)$ referentin näyttämölle ja merkitsee sen tällä tavoin roolihahmoksi.

Carloksen kuvaus poikkeaa myös aikamuodoltaan Aminan kuvauksesta. Amina vuoron mennyt aikamuoto kytkee kuvauksen Henryn hetkeä aiemmin esittämään kohtaukseen. Sen sijaan Carlos esittää kuvauksensa preesensissä, mikä siirtää kuvatun tilanteen puhehetkeen ja ikään kuin osanottajien silmien edessä tapahtuvaksi tässä ja nyt (Laitinen, 1998, dramaattinen preesens). Näin sekä vuoron kielellinen muotoilu että Carloksen kehollinen suuntautuminen kohti näyttämöä etäännyttävät kuvauksen Henrystä ja tämän äskeisestä toiminnasta. Ne rakentavat kuvausta niin, että se ohjaa muita näkemään kuvatun toiminnan fiktiivisen maailman tapahtumana ja sen toimijan esiintyjästä etäännytettynä roolihahmona.
Sekä Tuula (esimerkki 1) että Carlos (esimerkki 2) rakentavat roolihahmon toiminnan kuvausta tavalla, jonka voi nähdä ilmentävän orientoitumista fyysisen näyttämötilan merkityksiin sekä osanottajien kahdentuneeseen rooliin. Meneillään olevassa tilanteessa ja teatterityön kehyksessä Tuulan siirtyminen katsomosta sen edessä olevaan avoimeen tilaan rakentuu ja tulee nähdyksi näyttämölle astumisena (vrt. Goodwin 2000a, 2018; myös Goffman, 1974, s. 124-144). Tämä liikkuminen tilassa, näyttämölle astuminen, yhdessä puheen kanssa asemoi Tuulan kahdentuneeseen rooliin. Hän asettuu kehollisesti esityksen roolihahmoksi, jota hän puheellaan esiintyjän positiosta samanaikaisesti kommentoi. Vastaavasti Carlos hyödyntää merkityksiä, joita näyttämötilaan ja näyttämölle asettamiseen kytkeytyy. Hän tuo roolihahmon tilanteeseen mukaan kehollisella orientaatiollaan. Katseensa ja eleensä suunnalla hän asettaa kuvauksensa kohteena olevan, puheensa referentin näyttämölle ja tällä tavoin merkitsee referentin esittäjästään etäännytetyksi roolihahmoksi.

\section{OHJAAJA RAKENTAA OSANOTTAJIEN KAHDENTUNUTTA ROOLIA}

Tarkastelen seuraavaksi kahta esimerkkiä, joissa teatteriprojektin ohjaaja antaa osanottajille palautetta tehdystä harjoituksesta. Osoitan, miten hän vuorojensa muotoilulla tekee näkyväksi osanottajien kahdentuneen roolin esiintyjinä ja yleisön katseen kohteena olevina roolihahmoina. Näytän myös, miten hän samalla osoittaa yleisön katseen meneillään olevassa tilanteessa - roolihahmon toimintaa arvioitaessa - merkitykselliseksi. Yleisön katseen merkityksellisyyden osoittaminen rakentaa osaltaan teatterityön ammatillista katsetta. 


\subsection{Osanottajat esiintyjinä ja roolihabmoina}

Seuraavan katkelman voi nähdä kiteyttävän sen, mitä draamassa ja kahdentuneessa roolissa toimiminen merkitsee. Esimerkissä 3 ohjaaja Elina kommentoi osanottajien toimintaa harjoituksessa, jonka nämä ovat juuri tehneet

\section{Esimerkki (3) [U019_Status]}

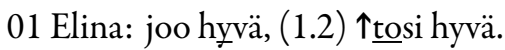

\section{3}

04

05 tulis olla $\underline{\text { ? }}$ (0.6) elikkä tavallaan +niinku tosi pie:net jutut, et se et +nousee seisomaan, astuu eteenpäin vaik te ootte siel laval ja teist [\#1] +et mun pitää korjata mun +korjaa vähän paidan helmaa roolihenkilö korjaa sitä paitaa, (.) ja sillon sen status pienenee. se mitä havaintoja mä teen tässä on se et mitä îsompi stạtus, (.) ni sitä, sitä, tota noin nin, hu:olellisempaa sen tekemisen tavallaan esiintyjänä tulee sellane olo paitaa, (.) mut siit kannattaa olla hyvin tietonen; (.) eli sillon myöski se teiän

Palautteessaan Elina kuvaa, miten suuren statuksen roolihahmon tulisi näyttämöllä toimia ja miksi. Hän nostaa eksplisiittisesti esiin harjoituksen tehneiden nuorten kaksi roolia harjoiteltavassa tilanteessa sekä roolien väistämättömän kytköksen. Nuoret ovat näyttämöllä toimivia ja kokevia esiintyjï (r. 9-13: vaik te ootte siel lavval ja teist tavallaan esiintyjänä tulee sellanen olo et mun pitää korjata mun paitaa). Mutta samanaikaisesti he ovat näyttämöllä roolihahmoja, joiden toimintana heidän toimintansa tulee nähdyksi ja tulkituksi (r. 14-16: eli sillon myöski se teiän roolihenkilökorjaa sitäpaitaa, (.) ja sillon sen status pienenee) (vrt. Goffman 1974, s. 124-144).

Merkityksellistä on myös, millaisiin toimintoihin näiden kahden roolin, esiintyjän ja roo- ja jossa he ovat kokeilleet statuksen ilmaisemisen keinoja. Katkelman alussa Elina istuu katsomon eturivissä ja osanottajat seisovat näyttämöllä, jossa ovat tehneet harjoituksen.

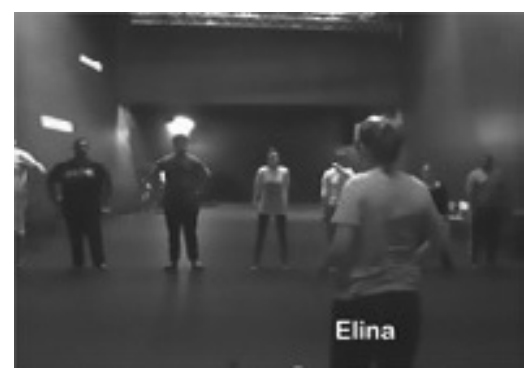

[\#1]

lihahmon, esiin nostaminen liittyy. Palautevuoron alussa Elina kuvaa, miten näyttämöllä tulisi (r. 6) ja kannattaa (r. 13) toimia. Tässä direktiivisessä jaksossa (r. 4-14) hän käyttää 1. ja 2. persoonan muotoja ja nollarakenteita, joissa ei ole tekijään viittaavaa elementtiä (nollarakenteista ks. Laitinen, 1995, 2006). Hän kuvaa esiintyjinä toimivien nuorten tuntemusta (teist tavallaan esiintyjänä tulee sellane ollo) ja korostaa esiintyjän näkökulmaa referoimalla tuntemusta 1. persoonassa (et mun pitää korjata mun paitaa). Myös jaksoa päättävä nollapersoonarakenne (mut siit kannattaa olla hyvin tietonen) kuvaa tilannetta toimijan, esiintyjän näkökulmasta viitaten tämän omien tuntemusten tiedostamiseen.

Tätä seuraa kuvaus siitä, mitä tapahtuu, 
jos esiintyjän tekeminen ei ole ohjeiden mukaista, huolellista ja tietoista (r. 14-16). Sitä aloittaa eli-partikkeli, joka puheessa merkitsee edellä sanotun parafraasia tai sen seurausten kuvausta; ammattilaisen ja asiakkaan keskusteluissa usein myös ammattilaisen selitystä, mitä asiakkaan edellä esittämä asia merkitsee instituution tulkintakehyksessä (Sorjonen, 2018, s. 267-272). Samalla Elina siirtyy 3. persoonan kuvaukseen (eli sillon myöski se teiän roolibenkilö korjaa sitä paitaa, (.) ja sillon sen status pienenee), mikä siirtää kuvatun toiminnan ja tapahtuman tarkastelupisteen esiintyjän ulkopuolelle. Näin edellä esitettyjen ohjeiden perusteluksi asetetaan se, millaisena esiintyjän toiminta näyttäytyy ja tulee tulkituksi katsojan silmin. Ohjeiden perusteleminen katsojan näkökulmalla osoittaa tämän näkökulman tilanteessa merkitykselliseksi - ohjattaessa ja arvioitaessa esiintyjän toimintaa roolihahmona.

Samaan aikaan Elina rakentaa vuoroaan myös kehollisesti, esittämällä toimintaa, jota hän puheellaan kuvaa. Esittäminen konkretisoi ja täydentää kielellistä kuvausta; kielellinen kuvaus puolestaan ohjaa vastaanottajien katsetta, havaintoja ja tulkintoja kehollisesta toiminnasta (C. Goodwin, 2000b, Keevallik, 2010,2013). Ryhtyessään havainnollistamaan huolellista tekemistä Elina nousee seisomaan ja astuu muutaman askeleen näyttämölle ( $r$. 8). Kuvatessaan esiintyjän tarvetta korjata paitaansa (r. 9-13: teist tavallaan esiintyjänä tulee sellane olo et mun pitää korjata mun paitaa), hän tekee pienen paidanhelmaa korjaavan eleen (kuva 1, r. 11-12) näyttäen, mihin puheella kuvattu tuntemus voi johtaa.

Ennen tätä kielellistä kuvausta ja siihen kytkeytyvää elettä Elina on maininnut huolellisen tekemisen ja pienten asioiden tärkeyden (r. 4-7). Maininta samoin kuin seisomaan nouseminen ja näyttämölle astuminen ennakoi kehollista demonstraatiota ja ohjaa nuoria kiinnittämään huomionsa siihen, mitä Elina kehollaan tekee. Elettä seuraa puolestaan eleen merkityksen kielellistäminen (r. 14-16: sillon myöski se teiän roolihenkilö korjaa sitä paitaa, (.) ja sillon sen status pienenee.). Se eksplikoi havainnon, tulkinnan ja päätelmän, joka nuorten olisi pitänyt Elinan kehollisesta toiminnasta tehdä.

\subsection{Osanottajien ybteinen positio ja etäännyttäminen}

Kognitiivisessa kieliopissa käytetyn näyttämömetaforan mukaan kielelliset rakenteet muodostuvat yhtäältä ilmauksen profiilista eli näyttämöstä ja toiseksi sen taustana olevasta implisiittisestä kehyksestä eli katsomosta, johon puhetilanteen osallistujat, puhuja (minä) ja kuulija (sinä), sijoittuvat (Langacker, esim. 1990; myös Visapää, 2008, s. 73-80). Tämän metaforan mukaisesti eri persoonamuodoissa esitetyt ilmaukset asemoivat puhetilanteen osallistujat eri tavoin suhteessa toisiinsa: 1. ja 2. persoonan ilmaukset asettavat puhetilanteen osallistujat katsomoon mutta toisen heistä (minut tai sinut) samalla myös ilmauksen profiiliin näyttämölle. Sen sijaan 3. persoonan ilmaukset asemoivat puhujan ja kuulijan samaan yhteiseen positioon katsomoon.

Voikin ajatella, että teatterityön harjoituksissa eri persoonamuotojen metaforisia merkityksiä käytetään astetta konkreettisemmassa tehtävässä kuin yleensä kielenkäytössä. Niitä hyödynnetään viittaamisen käytänteissä, joilla vuorovaikutuksen osanottajia asemoidaan erilaisiin positioihin osallistumiskehikossa. Kun ohjaaja vaihtaa palautevuoroissaan kuvauksensa näkökulmaa ja siirtyy 1. ja 2 . persoonan muodoista ja nollarakenteista 3. persoonan muotoihin, hän jättää kuvauksen kohteena olevan roolihahmon näyttämölle, mutta siirtää puhetilanteen osallistujat, itsensä sekä vastaanottajat yhteiseen positioon katsomoon, josta näyttämöllä olevaa roolihahmoa tarkastellaan (myös Raevaara, 2015, s. 176-183). 
Esimerkissä 4 ohjaaja Elina rakentaa palautevuoroaan osin samaan tapaan kuin edellisessä esimerkissä. Hän ohjeistaa harjoituksen tehneitä nuoria kuvaamalla ensin näyttämöllä oloa esiintyjän näkökulmasta, mutta muuttaa näkökulmaa ryhtyessään perustelemaan ohjeitaan. Katkelma on nauhoitettu myöhemmin samana päivänä kuin esimerkki 3, ja nuoret harjoittelevat edelleen statuksen ilmaise- misen keinoja. Tässä harjoituksessa statusta piti muuttaa oman parin kanssa vuorotellen niin, että toisen kasvattaessa statustaan toisen piti puolestaan pienentää statustaan. Tavoitteena oli statusmuutoksen ilmaiseminen vain yhdellä liikkeellä kerrallaan. Katkelman aikana nuoret istuvat katsomossa ja Elina tuolilla näyttämöllä heidän edessään.

\section{Esimerkki(4)[U022_Palaute]}

01 Elina: teitte tosi hyvää työtä, $>$ ja se mitä mä < sä_o $<$ se 02 oli îhanaa Tuula et sä sanoit että et Fẹi kuu:nteli?

03 se oli, tọsi hỵvä et sä puolustit Fê:itä; =ja sit mä 04 haluun tota, Feille viel sanoo sen että, ja 05 yhteisesti teille kaikille et se mitä mä oikeestaan 06 sil hetkel tarkotin oli se että; (.) et jos kaveri

$07+$ tekee [\#1] jonku yhel liii:kkeen (.) ni sit sej

$08+$ nostaa polvea, ottaa siitä käsillä kiinni

09 jälkee ku $\mathbf{0}$ on oma vuoro liii:kkua, nii et $\mathbf{0}$

10 pitäytyis siinä +et $\mathbf{0}$ tekee vaan ỵhen liikkeen. +laskee polven alas

elikä tavallaan että, (.) et, et jos esimerkiksi, (.) $\mathbf{0}$ on se oma vúuro, (.) ni et $\mathbf{0}$ on sillain tarkka et, $+(0.4)[\# 2]$ et se liike voi jäädä vaik tähän,

+nousee puoliksi seisovaan asentoon

(1.5) et $\mathbf{0}$ kuuntelee myös sitä +omaa liikettä

$$
\text { +istuutuu }
$$

koska, .hh periaatteessa; .mth tai se voi olla + nii et se nousee rivakasti siit iha ylös astí? + nousee seisomaan

(0.3) + mut sit heti jos se tekee esimerkiks näin; +istuutuu

(3.8) nousee seisomaan, laittaa käden lantiolle, siirtää jalkaa [\#3]

个ni täshä oli kolme liikettä; $+(1.5)>$ täs oli se et

$$
\text { +istuutuu }
$$

se nousi ylös? +(0.8) tsahh, laitto jalan, ++ (.) kakksi;

+nousee seisomaan ++siirtä̈ jalkaa +laitto käden; (.) kolme. (0.3) ni tää oli se mitä mä + laittaa käden lantiolle niinku, olin huomaavinani siin sun tekemisessä,= $\uparrow$ ja myös muiden tekemisissä,

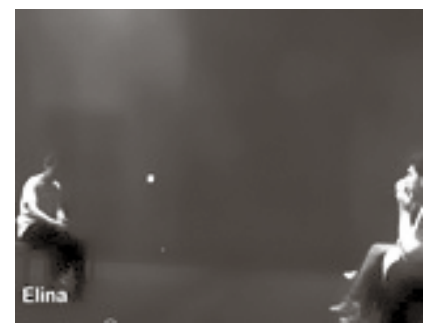

$[\# 1]$

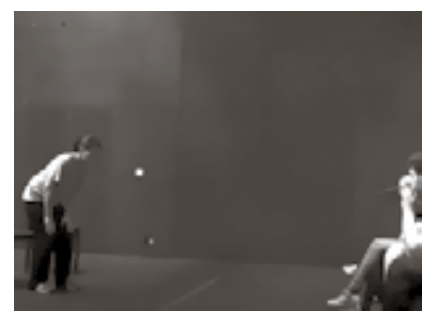

[\#2]

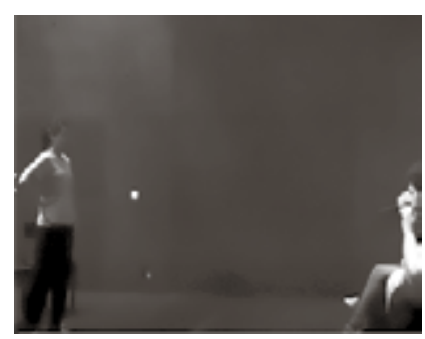

[\#3] 
Elina kytkee palautteensa ensin siihen, mitä on harjoituksen aikana havainnut (ks. myös esim. 3, r. 3) ja mistä on jo sanonut Feille, mutta suuntaa sitten puheensa myös kaikille muille (r. 1-6). Sen jälkeen hän ryhtyy kuvaamaan toimintaa, johon harjoituksessa pitäisi pyrkiä, rakentaen kuvausta lausumilla, joissa ei ole tekijään viittaavaa elementtiä (r. 6-17; tekijän "tyhjät paikat" on merkitty lausumiin nollilla). Nollarakenteet avaavat kaikille puhetilanteen osallistujille paikan asettua toimijan, harjoitusta tekevän esiintyjän asemaan (Laitinen, 1995, 2006). Myös esiintyjän mentaaliseen toimintaan viittaavat ilmaukset (r. 9-10: et pịtäytyis siinä et tekee; $r$. 14: on sillain tarkka; r. 17: et kuuntelee myös sitä omaa liikettä) rakentavat kuvausta esiintyjän näkökulmasta.

Tämän jälkeen Elina kuvaa, millaista toimintaa harjoituksessa tulisi puolestaan välttää ja miksi (r. 19-30). Jaksoa aloittaa koskapartikkeli (r. 19), joka puheessa tyypillisesti aloittaa perustelevia lausumia ja toimii argumentatiivisen suhteen merkkinä (Herlin, 1997; Raevaara, 2011). Samalla kuvauksen näkökulma vaihtuu, ja toimijaan viitataan nyt 3. persoonan pronominilla se (r. 20, 22, 27). Näkökulman vaihdos ohjaa vastaanottajia tarkastelemaan kuvattua toimintaa ulkopuolisesta näkökulmasta ja siirtää heidät näyttämöltä esiintyjän positiosta katsomoon. Samalla ulkopuoliseen näkökulmaan siirtyminen asettaa edellä esitettyjen ohjeiden perusteluksi sen, millaisena kuvattu toiminta näyttäytyy yleisölle.

Esimerkissä 3 ensiviittaus roolihahmoon tehdään leksikaalisella ilmauksella, joka kytkee hahmon eksplisiittisesti esiintyjään (r. 14-15: se teiän roolibenkilö). Tässä Elina siirtyy 3. persoonan kuvaukseen viittaamalla toimijaan pelkällä se-pronominilla (r. 20). Sekin kytkee referentin esiintyjiin mutta implisiittisemmin. Tällainen pelkällä se-pronominilla tehty viittaus tilanteessa, jossa referenttiä ei ole mainittu edellä, ohjaa vastaanottajia käsittelemään referenttiä tilanteessa tunnettuna - tunnistettavana sen kontekstin avulla, jonka aiempi puhe ja toiminta ovat luoneet (Etelämäki, 2006, s. 96-117, 2009; Seppänen, 1998, s. 45-58; myös Laury, 1994). Se-viittaus osoittaakin tässä, että osanottajien kahdentunutta roolia käsitellään nyt jo yhteisesti tunnettuna tietona ja tulkintakehyksenä.Sen mukaisesti edeltävä puhe esiintyjien toiminnasta tekee tilanteessa tunnistettavaksi myös esiintyjien toiminnan luoman roolihahmon.

Samalla se-viittaukset myös etäännyttävät kuvauksen äskeisestä harjoitustilanteesta ja yksittäisten esiintyjien suorituksesta. Ryhtyessään kuvaamaan vältettävää toimintaa Elina asettaa se-pronominilla toimijaksi fiktiivisen roolihahmon, joka ei ole kenenkään tietyn esiintyjän luoma vaan pikemminkin kaikkien yhteisen toiminnan kautta tunnistettava. Siten $s e$-viittauksin rakennettu näkökulman vaihdos toimii yhtä aikaa sekä kytkennän että etäännyttämisen keinona, joka ilmentää teatterille ominaista fiktion ja todellisuuden suhdetta, yhtäaikaista kytköstä ja erillisyyttä (vrt. Eriksson, 2009, s. 35-46; Heikkinen, 2004, s. 85-90).

\subsection{Analyyttinen katse}

Samanaikaisesti kielellisen kuvauksen kanssa ohjaaja rakentaa palautettaan myös kehollisesti. Jo esimerkin 4 alussa, kommentoidessaan Tuulan toimintaa harjoituksen aikana Elina säestää puhettaan eleillä (r. 1-3). Hetkellä, jolloin hän ryhtyy kuvaamaan ja ohjeistamaan sitä, miten esiintyjien tulisi harjoituksessa toimia, hänen kehollisen toimintansa rytmissä tapahtuu kuitenkin selvä muutos: liikkeet hidastuvat ja muuttuvat täsmällisiksi ja keskittyneiksi. Rytminmuutos merkitsee asettumista näyttämölle harjoitusta tekevän esiintyjän positioon. Samalle se kutsuu katsomossa istuvia nuoria suuntaamaan huomionsa Elinan 
keholliseen toimintaan. Elina näyttää ensin statusta pienentäviä ja kasvattavia yksittäisiä liikeitä, joihin harjoituksessa pyrittiin (kuva 1, r. 7-8; kuva 2, r. 15-16; myös r. 21). Sen jälkeen hän esittää esimerkin toiminnasta, joka koostuu useasta liikkeestä (kuva 3, r. 24).

Tutkimuksessaan tanssituntien vuorovaikutuksesta Leelo Keevallik $(2010,2013)$ tarkastelee sitä, miten opettaja käyttää puhetta ja kehollista toimintaa oppilaiden ohjaamisessa. Opettaja muun muassa esittää kehollisia lainauksia oppilaiden asennoista ja liikkeistä, jotka vaativat korjaamista. Niitä edeltää usein kielellinen kehystys, jolla opettaja kytkee lainauksen oppilaiden aiempaan toimintaan mutta kuitenkin sellaisen yleisen viittauksen avulla, joka ei liitä lainausta kehenkään yksittäisen oppilaaseen (2010, s. 411,414). Lainausten rinnalla opettaja demonstroi kehollisesti myös tavoitteena olevia liikkeitä. Keholliset lainaukset toimivat oppilaille peilinä, josta nämä voivat nähdä ja tunnistaa korjattavia kohtia omassa kehollisessa toiminnassaan. Rinnastettuna tavoiteltavaan toimintaan ne myös auttavat heitä havaitsemaan väärien ja oikeiden liikkeiden ja asentojen eron. On lisäksi tavallista, että opettaja korostaa tätä eroa esittämällä kehollisissa lainauksissaan liioitellun tai karrikoidun version korjaamista vaativista oppilaiden liikkeistä.

Myös teatterityön harjoituksissa ohjaajan kehollinen toiminta on peili, josta nuoret voivat nähdä, miltä heidän toimintansa näyttää. Useasta liikkeestä koostuva kehollinen demonstraatio, jonka Elina esittää vuoronsa lopussa (r. 22-30), havainnollistaa korjattavaa toimintaa, johon hän on jo harjoituksen aikana puuttunut. Sitä edeltää kielellinen kehystys, jota aloittava mutta-partikkeli merkitsee kontrastia edellä esitettyjen liikkeiden ja seuraavan toiminnan välillä (r. 22: $m u t$ sit heti jos se tekee esimerkiks näin) (ks. myös Keevallik, 2013; kielellisestä kehystyksestä projisoimassa kehollista toimintaa). Kielel- lisestä kontrastoinnista huolimatta Elina ei kuitenkaan kehollisesti liioittele tai karrikoi esimerkkiä usean liikkeen statusmuutoksesta (vrt. Keevallik, 2010). Sen sijaan hän toistaa demonstraation pilkkoen sekä kehollisen esityksen että kielellisen kuvauksen osiin (r. 25-30) ja auttaa näin nuoria näkemään eron eri toimintatapojen välillä.

On tavallista, että ohjaaja palautevuoroissaan havainnollistaa kehollisesti niitä toimintatapoja, joita hän on harjoituksen aikana havainnut mutta jotka eivät ole harjoituksen tavoitteiden mukaisia (esimerkit 3 ja 4). Hän kuitenkin esittää ne ilman liioittelua ja kontrastointia tavoitteena olevaan toimintaan, pikemminkin hienovaraisesti kuin korostaen (esimerkki 3). Näin hän ohjaa nuoria kiinnittämään huomiota kehollisten demonstraatioidensa yksityiskohtiin ja havainnoimaan niitä tarkasti. Tapa, jolla ohjaaja kehollisesti nostaa esiin huomioitaan projektin osanottajien toiminnasta harjoitusten aikana, näyttää erilaiset toimintatavat vaihtoehtoina, jotka eivät ole niinkään oikeita tai väärïä vaan pikemminkin valintoja, jotka synnyttävät katsojissa erilaisia tulkintoja ja merkityksiä.

Vuorovaikutuksen käytänteet, jotka tekevät näkyväksi teatteriprojektin osanottajien kahdentuneen roolin esiintyjinä ja roolihahmoina, ovatkin myös käytänteinä, jotka osaltaan rakentavat osanottajien ammatillista katsetta. Ne ohjaavat heidän tapaansa nähdä, arvioida ja tulkita omaa ja toistensa toimintaa esiintyjinä, liikkumista ja positioita tilassa. Kahdentuneen roolin omaksuminen tarkoittaa myös kykyä asettua katsomaan, analysoimaan ja arvioimaan esiintyjän toimintaa ulkopuolisesta, yleisön näkökulmasta sekä kykyä nähdä toiminta esittäjästään etäännytetyn roolihahmon toimintana, osana yhteistä esitystä. 


\section{TEATTERINTYÖN VUOROVAIKUTUSKÄYTÄNTEET JA AMMATILLINEN KATSE}

Artikkelissani olen tarkastellut nuorille aikuisille suunnatun teatteriprojektin harjoituksia. Tutkin harjoituksiin sisältyviä tilanteita, joissa puhutaan roolihahmona toimimisesta ja tämän toiminnan rakentamista roolihahmoista. Analysoin sitä, miten osanottajien vuorojen kielellinen muotoilu ja samanaikainen kehollinen toiminta ja tilan käyttö rakentavat roolihahmon tarkastelun näkökulmia. Vuorovaikutuksen käytänteet ja yksityiskohdat, joilla näitä näkökulmia vaihdellaan ja limitetään, tekevät meneillään olevassa toiminnassa näkyväksi osanottajien kahdentuneen roolin esiintyjinä ja roolihahmoina rakentaen samalla teatterityön ammatillista katsetta.

Draamakasvatuksessa teatterille ominaista kahdentuneessa roolissa toimimista on yleensä tarkasteltu kognitiivisena ilmiönä, tietoisuutena siitä, että fiktiiviset roolit ja todellisuus ovat yhtäältä erillisiä mutta samalla myös erottamattomasti ja samanaikaisesti läsnä (esim. Heikkinen, 2004, s. 85-90; myös Eriksson, 2009, s. 35-46). Artikkelissani olen sen sijaan näyttänyt, millaisin erilaisin tavoin teatteriprojektin osanottajien kahdentunut rooli ilmenee vuorovaikutuksen konkreettisissa yksityiskohdissa (myös Ihalainen, 2017, tulossa).

Teatterityön harjoituksissa osanottajien roolien rakentamisessa ja jäsentämisessä käytetään paitsi puhetta usein myös kehollista toimintaa sekä fyysiseen tilaan, näyttämöön ja katsomoon kytkeytyviä merkityksiä. Astumalla näyttämölle on mahdollista asettua kehollisesti roolihahmon positioon, ei vain esitystilanteissa tai harjoituksen alkaessa, vaan myös keskusteltaessa roolihahmojen ja niitä rakentavien esiintyjien toiminnasta. Näyttämölle ja sen myötä roolihahmoksi asettumista voidaan merkitä tai korostaa myös muutoksella kehollisen toiminnan tavassa. Esimerkiksi liikkeiden hitaampi tempo ja täsmällisyys ohjaa muita näkemään ja tulkitsemaan toiminnan esityksenä. Lisäksi kielellisen kuvauksen kohteena oleva puheen referentti voidaan asettaa näyttämölle ja merkitä roolihahmoksi puhujan kehollisella orientaatiolla, esimerkiksi näyttämötilaan suuntautuvalla katseella tai osoittavalla eleellä.

Kielellisen ja kehollisen toiminnan yhtäaikaisuus voi asemoida toimijan myös kahteen erilliseen mutta toisiinsa kytkeytyvään osallistujapositioon ja siten rakentaa hänen kahdentunutta rooliaan esiintyjänä ja roolihahmona. Projektin osanottaja voi esimerkiksi esittää roolihahmonsa toimintaan liittyvän kysymyksen, jonka kielellinen muotoilu asettaa hänet esiintyjän asemaan ja poimii vastaanottajaksi ohjaajan. Hän voi kuitenkin samalla astua näyttämölle ja asettua siten kehollisesti kielellisen kuvauksen kohteena olevaksi roolihahmoksi. Näyttämölle astuminen laajentaa meneillään olevan toiminnan osallistumiskehikkoa. Se kutsuu paitsi ohjaajan myös kaikki muut läsnäolijat katsomaan ja arvioimaan kehollista esitetystä, mikä muokkaa toiminnasta kollektiivisempaa ja rakentaa teatterin tekemiselle ominaista yhteisöllisyyttä (myös Visakko, 2020a, 2020b).

Roolihahmon tarkastelun erilaisia näkökulmia ja osanottajien kahdentunutta roolia voidaan rakentaa myös vuorojen kielellisellä muotoilulla. Muun muassa harjoituksiin liittyvissä palautevuoroissaan ohjaaja käyttää tyypillisesti 2. persoonan muotoja tai nollarakenteita vuoronsa direktiivisissä osissa asettaen näin toimijaksi roolihahmoa rakentavan esiintyjän. Sen sijaan ohjeita perustellessaan hän viittaa toimijaan 3. persoonan muodoilla, usein pelkällä se-pronominilla. Tämä näkökulman vaihdos asettaa näyttämölle esiintyjistä etäännytetyn roolihahmon ja siirtää 
puheen vastaanottajat esiintyjän positiosta katsomoon ohjaten heitä tarkastelemaan roolihahmon toimintaa ulkopuolisesta näkökulmasta. Samalle se nostaa edellä esitettyjen ohjeiden perusteluksi ja tilanteessa merkitykselliseksi sen, millaisena roolihahmon toiminta näyttäytyy yleisölle.

Palautevuoroissaan ohjaaja useimmiten esittää kuvaamaansa toimintaa myös kehollisesti. Kehollinen esittäminen havainnollistaa ja täydentää kielellistä kuvausta, ja kielellinen kuvaus puolestaan ohjaa vastaanottajien katsetta ja tulkintoja, kun he havainnoivat kehollista toimintaa (Keevallik, 2010, 2013; myös C. Goodwin, 2000b). Samalla ohjaaja kehollinen toiminta on projektin osanottajille peili, josta he voivat nähdä, miltä heidän toimintansa näyttää yleisön silmin, mihin heidän tulisi harjoituksessa pyrkiä ja mitä välttää, ja jonka avulla he voivat oppia havaitsemaan kehollisen toiminnan yksityiskohtia ja niiden luomia tulkintoja.

Kielenkäytön, kehollisen toiminnan ja fyysisen ympäristön merkitykset omaksutaan sosiaalisessa toiminnassa. Siten myös koulutus ja työssä kertyvä kokemus ja usein tiedostamatonkin tieto ohjaavat osaltaan sitä, miten vuorovaikutuksessa tulkitaan ja hyödynnetään kielellistä ja kehollisia toimintaa, fyysistä ympäristöä ja materiaalisia objekteja (C. Goodwin, 2000a, 2000b, 2018). Artikkelissani olen valottanut teatteriharjoitusten vuorovaikutuskäytänteitä ja näyttänyt, millaisin kielellisin ja kehollisin resurssein teatteriprojektin osanottajat rakentavat ja muokkaavat asemiaan meneillään olevan toiminnan osallistumiskehikossa ja sen myötä teatterin tekemiseen liittyviä roolejaan. Olen osoittanut, miten tarkastelemieni tilanteiden vuorovaikutuskäytänteet ja toiminnan yksityiskohdat tekevät näkyväksi yhdenlaisen ammatillisen tilanteen, teatterityön ominaisia tapoja nähdä ja tulkinta vuorovaikutuksen osanottajien kielellistä ja kehollista toimintaa, liikkumista ja positioita tilassa (vrt. esim. Deppermann \& Streeck, 2018; Haddington ym., 2013; Harjunpää ym., 2018; Mortensen \& Hazel, 2014; Sorjonen \& Raevaara, 2014).

Teatteriprojektiin osallistuvilla nuorilla ei ollut aiempaa kokemusta teatterin tekemisestä. Projektin aikana he harjoittelivat roolihahmoksi muuntautumisen tapoja ja tekniikoita sekä teatterityön ammatillista katsetta. Yhteisessä työssä ja toiminnassa he oppivat analysoimaan ja arvioimaan luomiaan roolihahmoja yleisön näkökulmasta ja osana tulevaa esitystään. He omaksuivat kielellisiä ja kehollisia vuorovaikutuskäytänteitä, joilla etäännyttää roolihahmon tarkastelu sen esittäjästä ja joilla asettaa se yhteisen arvioinnin kohteeksi. He omaksuivat tavan katsoa kehollisen toiminnan vaihtoehtoja ja yksityiskohtia valintoina, joilla luoda erilaisia tulkintoja ja merkityksiä.

\section{Kiitokset}

Kiitän kahta nimetöntä arvioijaa tarkoista ja erittäin asiantuntevista ja arvokkaista kommenteista. Kiitos Koneen Säätiölle hankkeemme rahoittamisesta. Suureen suuri ja lämmin kiitos kaikille hankkeen taiteentekijöille, tutkijoille ja teatteriprojektien nuorille oivalluksista, pohdinnoista, ymmärryksestä, hauskuudesta ja suurista tunteista. 


\section{LÄHTEET}

Antaki, C. (toim.) (2011). Applied Conversation Analysis. Palgrave Advances in Linguistics. London: Palgrave Macmillan.

Deppermann, A. \& Streeck, J. (toim.) (2018). Time in Embodied Interaction. Synchronicity and sequentiality of multimodal resources. Amsterdam: John Benjamins.

Drew, P. \& Heritage, J. (toim.) (1992). Talk at work. Interaction in institutional settings. Cambridge: Cambridge University Press.

Eriksson, S. (2009). Distancing at Close Range. Investigating the Significance of Distancing in Drama Education. Turku: Åbo Akademi.

Etelämäki, M. (2006). Toiminta ja tarkoite. Tutkimus suomen pronominista tämä. Helsinki: Suomalaisen Kirjallisuuden Seura.

Goffman, E. (1981). Forms of talk. Oxford: Bacil Blackwell.

Goffman, E. (1974). Frame analysis. An Essay on the Organization of Experience. Boston: Northeastern University Press.

Goodwin, C. (1979). The interactive construction of a sentence in natural conversation. Teoksessa G. Psathas (toim.), Everyday Language: Studies in Ethnomethodology, (s. 97-118). New York: Erlbaum.

Goodwin, C. (1994). Professional vision. American Anthropologist, 96, 606-633.

Goodwin, C. (2000a). Practices of seeing: Visual Analysis: An Ethnomethodological Approach. Teoksessa T. van Leeuwen \& C. Jewitt (toim.), Handbook of Visual Analysis, (s. 157-182). London: Sage.

Goodwin, C. (2000b). Action and embodiment within situated human action. Journal of Pragmatics, 32, 1489-1522.

Goodwin, C. (2007). Interactive footing. Teoksessa E. Holt \& R. Clift (toim.), Reporting talk: Reported speech in Interaction, (s. 16-46). Cambridge: Cambridge University Press.

Goodwin, C. (2018). Why multimodality? Why co-operative action? (transcribed by J. Philipsen). Social Interaction. Video-Based Studies of Human Sociality, 1(2). doi: https:// soi.org/10.7146/si.v1i2.110039.

Goodwin, C. \& M.H. Goodwin, M. H. (1992) Context, activity and participation. Teoksessa P. Auer \& A. di Luzo (toim.), The contextualization of language, (s. 77-99). Amsterdam: John Benjamins.
Goodwin, C. \& Goodwin, M.H. (2004): Participation. Teoksessa A. Duranti (toim.), A Companion to Linguistic Anthropology, (s. 222-244). Oxford: Blackwell.

Goodwin, M.H. (1980). Processes of mutual monitoring implicated in the production of description sequences. Sociological Inquiry, 50, 303-317.

Haddington, P., Mondada, L. \& Nevile, M. (toim.) (2013). Interaction and mobility: Language and the body in motion. Berlin: De Gruyter.

Harjunpää, K., Mondada, L. \& Svinhufvud, K. (2018). The coordinated entry into service encounters in food shops: Managing interactional space, availability and service during openings. Research on Language and Social Interaction, 51, 271-291.

Harjunpää, K., Mondada, L. \& Svinhufvud, K. (2019). Multimodaalinen litterointi keskustelunanalyysissa. Pube ja kieli, 39, 195220.

Harjunpää, K., Deppermann, A. \& Sorjonen, M-L. (2021). Constructing the Chekhovian inner body in instructions: An interactional history of factuality and agentivity. Journal of Pragmatics, 171, 158-174.

Hazel, S. (2015). Acting, interacting, enacting - representing medical practice in theatre performance. Teoksessa M. Kjær, J. L. Jørgensen \& A. Holm Riis (toim.), Thematic Issue on 'Health', Akademisk Kvarter/Academic Quarter 12, (s. 44-64). Aalborg University.

Hazel, S. (2018). Discovering interactional authenticity: Tracking theatre practitioners across rehearsals. Teoksessa G. Martinez, J. Wagner, S. Pekarek Doehler (toim.), Longitudinal Studies on the Organization of Social Interaction, (s. 255-283). London: Palgarve Macmillan.

Heath, C. (1986). Body Movement and Speech in Medical Interaction. Cambridge: Cambridge University Press.

Heikkinen, H. (2004). Vakava leikillisyys. Draamakasvatusta opettajille. Helsinki: Kansanvalistusseura.

Heritage, J. (1996) [1984]: Harold Garfinkel ja etnometodologia. Helsinki: Gaudeamus.

Herlin, I. (1997). Suomen kielen koska-konjunktion merkitys ja merkityksenkehitys. Helsinki: Suomalaisen Kirjallisuuden Seura. 
Ihalainen, L. (2017). Muuntumisen vuovaikutuskäytänteet teatterityöskentelyssä. Kandidaatintutkielma. Draamakasvatus, Jyväskylän yliopisto.

Ihalainen, L. (tulossa). Muuntumisen vuorovaikutuskäytänteet teatteriharjoituksissa. Väitöskirjan käsikirjoitus. Helsingin yliopisto.

Izarra, E. \& Sirviö, S. (toim.) (2018). Alkumetreillä. Väläyksiä erä̈n teatterin ja kaupungin organisoimasta kesäduuniprojektista. Helsinki: URB-festivaali ja Taide työnä ja työvälineenä -tutkimushanke.

Keevallik, L. (2010). Bodily Quoting in Dance Correction. Research on Language and Social Interaction, 43, 401-426.

Keevallik, L. (2013). The Interdependence of Bodily Demonstrations and Clausal Syntax. Research on Language and Social Interaction, 46, 1-21.

Koivisto, A. (2013). On the Preference for Remembering: Acknowledging an Answer with Finnish Ainii (n) ("Oh that's right"). Research on Language and Social Interaction, 46, 277-297.

Laitinen, L. (1995). Nollapersoona. Virittäjä, 99, 337-357.

Laitinen, L. (1998). Dramaattinen preesens poeettisena tekona. Teoksessa L. Laitinen \& L. Rojola (toim.), Sanan voima. Keskusteluja performativisuudesta, (s. 81-136). Helsinki: Suomalaisen Kirjallisuuden Seura.

Laitinen, L. (2006). Zero person in Finnish. A grammatical resource for construing human reference. Teoksessa L. Cambell \& M.-L. Helasvuo (toim.), Grammar from the human perspective, (s. 209-231). Amsterdam: John Benjamins.

Langacker, R. (1990). Subjectification. Cognitive Linguistics, 1, 5-38.

Laury, R. (1994). Se ensimaininnan pronominina puhutussa suomessa. Virittäjä, 98, 277-279.

Malaska, J. (2016). Välitöntä toimintaa vaativat direktiivit teatteriharjoituksissa. Pro gradu -tutkielma. Suomen kieli, Helsingin yliopisto.

Mondada, L. (2014). Requesting Immediate Action in the Surgical Operating Room: Time, Embodied Resources and Praxeological Embeddedness. Teoksessa P. Drew \& E. Couper-Kuhlen (toim.), Requesting in Social Interaction, (s. 276-302). Amsterdam: John Benjamins.
Mondada, L. (2018). Multiple temporalities of language and body in interaction. Challenges for transcribing multimodality. Research on Language and Social Interaction, 51, 85-106.

Mortensen, K. \& Hazel, S. (2014). Moving into Interaction - Embodied Practices for Initiating Interactions at a Help Desk Counter. Journal of Pragmatics, 62, 46-67.

Nevile, Maurice 2015: The embodied turn in research on language and social interaction. Research on Language and Social Interaction, 48, 121-151.

Norrthon, S. (2020). Teaterrepetitionens interaktion. Professionella praktiker $i$ ett repetitionsarbete frän manus till föreställning. Stockholm Studies in Scandinavian Philology, New Series 68. Stockholms universitet.

Peräkylä, A. \& Vehviläinen, S. (2003). Conversation analysis and the professional stocks of interactional knowledge. Discourse and Society, 14, 727-750.

Raevaara, L. (2011). Accounts at convenience stores. Doing dispreference and small talk. Journal of Pragmatics, 4, 556-571.

Raevaara, L. (2015). Hyvä päivä olla minä, mä ja meitsi - minän vaihtelevat asemat ja identiteetit helsinkiläisnuorten puheessa. Teoksessa M-L. Sorjonen, A. Rouhikoski \& H. Lehtonen (toim.), Helsingissä puhuttavat suomet. Kielen indeksisyys ja sosiaaliset identiteetit, (s. 174213). Helsinki: Suomalaisen Kirjallisuuden Seura.

Sacks, H. (1992). Lectures on Conversation. Toimittanut Gail Jefferson. Cambridge: Basil Blackwell.

Sacks, H., Schegloff, E. \& Jefferson, G. (1974). A simplest systematic on turn-taking in conversation. Language, 50, 696-735.

Savijärvi, M. \& Ihalainen, L. (tulossa). How an improvised scene emerges in theatre rehearsal? Constructing coherence by recycling. Teoksessa J. Lindström, R. Laury, A. Peräkylä \& M.-L. Sorjonen (toim.), Intersubjectivity in Action: Studies in Language and Social Interaction. Amsterdam: John Benjamins.

Schegloff, E. (2007). Sequence Organization in Interaction. A Primer in Conversation Analysis. Cambridge: Cambridge University Press 
Schmidt, A. (2014). Spiel oder nicht Spiel? Zur interaktiven Organisation von Übergängen zwischen Spielweltund Realwelt in Theaterproben. Mannheim: Verlag für Gesprächsforschung.

Schmidt, A. (2018). Prefiguring the future. Projections and preparations within theatrical rehearsals. Teoksessa A. Deppermann \& J. Streeck (toim.), Time in Embodied Interaction. Synchronicity and sequentiality of multimodal resources, (s. 231-260). Amsterdam: John Benjamins.

Seppänen, E.-L. (1998). Läsnäolon pronominit.

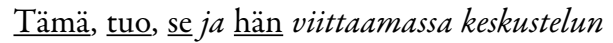
osallistujaan. Helsinki: Suomalaisen Kirjallisuuden Seura.

Sorjonen, M.-L. (2018). Reformulating prior speaker's turn in Finnish. Turn initial siis, eli(kkä), and nii(n) et(tä). Teoksessa J. Heritage \& M.-L. Sorjonen (toim.), Between turn and sequence. Turn initial particles across languages, (s. 251-285). Amsterdam: Benjamis.

Sorjonen, M.-L. \& Raevaara, L. (2014). On the grammatical form of requests at the convenience store: Requesting as embodied action. Teoksessa P. Drew \& E. Couper-Kuhlen (toim.), Requesting in social interaction, (s. 234268). Amsterdam: Benjamins.

Stevanovic, M. \& Lindholm, C. (toim.) (2016). Keskustelunanalyysi. Tampere: Vastapaino.

Turunen, A. (2018). Nauramisen normit: Nauruun liittyvä metapube nuorten aikuisten teatteriprojektissa. Pro gradu, HY.

Visakko, T. (2017). Ihmisen esittämisestä - roolit arjessa ja teatterissa. Verkkolehti Kansallinen Dynamiikka 24.10.2017. (http://kansallinendynamiikka.fi/ihmisenesittamisesta-roolit-arjessa-ja-teatterissa/)

Visakko, T. (2020a).Looking at the Self in Society: Professional Perception and Midgroundable Roles in Community Theater. Signs and Society, 8, 262-289. https://www.journals.uchicago. edu/doi/full/10.1086/707828

Visakko, T. (2020b). Becoming Artists: Collective Reflection of Personal Experience in Community Theater. Signs and Society, 8, 369-400.https://www.journals.uchicago.edu/ doi/full/10.1086/710155

Visapää, L. (2008). Infinitiivi ja sen infiniittisyys. Tutkimus suomen kielen itsenäisistä A-infinitivikonstruktioista. Helsinki: Suomalaisen Kirjallisuuden Seura. 


\section{STAGE CHARACTERS IN SPEECH AND ON STAGE - PARTICIPATION FRAMEWORK AND PROFESSIONAL VISION IN THEATRE REHEARSALS}

Liisa Raevaara, University of Helsinki, Institute for the Languages of Finland

The article examines rehearsals of a theatre project for young adults, and episodes during which the stage characters are talked about. It draws from and contributes to the conversation analytic line of research focusing on the use and coordination of multimodal resources in interaction. It also connects to studies analyzing different ways of referring to participants in interaction. Analysis of videotaped data shows how the participants - through the choice of verbal forms referring to the stage character and through varied embodied resources - modify participation framework and approach the character from different viewpoints. By learning these practices constructing different viewpoints, the participants of the project adopt the buildings blocks of the professional vision in theatre making.

Keywords: conversation analysis, multimodality, participation framework, professional practises, referring, theatre interaction 